\section{Journal of Sciences and \\ Engineering}

Vol. 4, $\mathrm{N}^{\circ} 2,2020$

\title{
Reduction of hexavalent chrome from artificial effluent of chrome: Batch electrocoagulation method [Reducción del cromo hexavalente de efluente artificial de cromado: Método de electrocoagulación por lotes]
}

Hans R. Portilla ${ }^{a}$, Aldo R. Castillo ${ }^{a}$,Cesar P. Arévaloa ${ }^{a}$ Fabio Cabrerab, Juan A.Vegaa ${ }^{a}$ Alexander Y. Vegab

\author{
a Escuela de Ingenieria Metalurgica, Universidad Nacional de Trujillo - Av Juan Pablo s/n - \\ Trujillo, Peru. \\ ${ }^{b}$ Escuela de Ingenieria de Materiales, Universidad Nacional de Trujillo - Av Juan Pablo s/n - \\ Trujillo, Peru. \\ *alrocas@unitru.edu.pe
}

Received: 30 November 2020; Accepted: 02 December 2020; Published: 06 December 2020

\section{Resumen}

En el presente trabajo de investigación, se evaluó el tiempo de tratamiento, relación área de electrodos/volumen de efluente, sobre el \% de reducción del cromo hexavalente en efluentes artificiales de cromado, mediante el método de electrocoagulación en batch; método para el cual se utilizaron ánodos y cátodos de acero A-36 de $(5.0 \times 5.0 \times 0.2) \mathrm{cm}$. La cantidad de electrodos y la separación entre ellos, se varió al fin de variar la relaciona área de electrodos/volumen de efluente y; para un reactor de electrocoagulación de tipo batch en el cual se realizaron 27 ensayos; manteniendo constante el volumen de efluente tratado. De los resultados obtenidos se determinó que el incremento del tiempo de electrocoagulación y la relación área de electrodos/volumen de efluente, influyen en el porcentaje de reducción de cromo hexavalente de los artificiales de cromado, tal como se apoya con el ANOVA y prueba F; el porcentaje de reducción máximo alcanzado fue de $91.65 \%$, respecto a la concentración inicial (20 $\mathrm{mg} / \mathrm{L}$ ), para un tiempo de ensayo de 60 minutos y una relación de área de electrodos/volumen de efluente de $0.912 \mathrm{~m}^{2} / \mathrm{L}$.

Palabras clave: Electrocoagulación, Efluentes de Cromado, Cromo, lotes.

\begin{abstract}
The present research evaluated treatment time, electrode area / effluent volume ratio, on the\% reduction of hexavalent chromium in artificial chrome plating effluents, was evaluated by the batch electrocoagulation method; Method for which A-36 steel anodes and cathodes of $(5.0 \times 5.0 \times 0.2) \mathrm{cm}$ were used. The number of electrodes and the separation between them was varied in order to vary the ratio of electrode area / effluent volume and; for a batch type electrocoagulation reactor in which 27 tests were carried out; keeping the volume of effluent treated constant. From the results obtained, it was determined that the increase in the electrocoagulation time and the electrode area / effluent volume ratio influence the percentage of hexavalent chromium reduction of the artificial chromium plating, as supported by ANOVA and test F; the maximum reduction percentage achieved was $91.65 \%$, with respect to the initial concentration $(20 \mathrm{mg} / \mathrm{L})$, for a test time of 60 minutes and a ratio of electrode area / effluent volume of $0.912 \mathrm{~m}^{2} / \mathrm{L}$.
\end{abstract}

Keywords: Electrocoagulation, Chrome Effluents, Chrome, batch.

\section{Introduction}

The generic name of the electroplating sector is "surface treatment". It is the process by which the characteristics of the surface of a base metal or other material are altered, by depositing a metallic coating that has desirable characteristics, carried out by means of electrolysis, in order to increase its ability to resist corrosive agents. and / or abrasives, improve their properties, their appearance and / or the usefulness of the metallic product. The greatest environmental impact of the sector concerns liquid effluents and eventually 
Vol. 4, $\mathrm{N}^{\circ}$ 2, 2020

Copyright @ 2020, CINCADER.

ISSN 2523-9503

DOI: https://doi.org/10.32829/sej.v4i2.192

\section{SE \\ Journal of Sciences and Engineering}

the sludge from the treatment of such effluents that contain heavy metals. The electroplating industry involves water consumption, both in the process baths and in the washing and rinsing stages (Salvadó, 2001). There are different systems for treating wastewater from chrome plating plants using this type of bath to treat metal surfaces. These waters are considered among the most dangerous industrial effluents due to their content of ferric, chromic and chromate ions in acid solution. Chromium (VI), an element of high toxicity, is found in appreciable quantities in their effluents, both in exhausted baths and in washing waters. Washing water is the main pollution problem, due to its large volume, although it is characterized by being very dilute (usually its chromium concentration is $20 \mathrm{mg} / \mathrm{L}$, normally $80 \%$ of the chromium used in the process is wasted). The most industrially used treatments for the removal of chromium (VI) are based on physicochemical or ion exchange processes, or combinations thereof. When the wastewater does not contain chromium (VI) ions and only contains heavy metal ions, these can be precipitated as hydroxides and be separated in a simple way, either by filtration or by sedimentation. However, most of the wastewater from chrome plating plants contains chromium (VI) ions, the treatment is less simple, requiring more complex and sophisticated techniques, such as electrochemical ones. The effects of chromium plating effluent with a high chromium and sulfate content, along a pollution gradient, in zooplankton communities in the Las Prusianas stream, in Santa Fe, Argentina are related to some physicochemical and biological parameters to evaluate the impact on zooplankton. The $\mathrm{Cr}$ and Sulfur values found were raised to the allowed standards. The electroplating plants that are located in the city of Trujillo, with few exceptions, have obsolete technology, lack qualified personnel and do not carry out control of the composition that normalizes their procedures for the treatment and disposal of the effluents they emit, much less control their production processes to minimize heavy metal pollutants, the decrease in chromium in effluents, originating a gap in the incorporation of the environmental factor in the planning of their productive activities (Morello, 2020; Metcalf and Eddy, 1995). The Presidency of the Council of Ministers, establish Maximum Permissible Limits of Liquid Effluents (Decreto supremo No. 037-2008-PCM), decrees in article 1, the maximum allowable limits (LMP) of liquid effluents for industrial activities; The values that are detailed below: that for hexavalent chromium the maximum limit is $0.1 \mathrm{mg} / \mathrm{L}$ and for total chromium it is $0.5 \mathrm{mg} / \mathrm{I}$ (Diario El Peruano, 2008).

In Peru, few studies have been carried out on the toxicity of heavy metals in wastewater, using the electrocoagulation method. Taking as working parameters the concentration of pollutants, $\mathrm{pH}$, electric potential and turbidity, the study achieved a greater elimination of chromium VI using iron and aluminum electrodes (Bazrafshan et al., 2008); considering $\mathrm{pH}$, current density and operating time as study variables; their results showed that the COD removal efficiency increased to $72.28 \%$ for the electrocoagulation process with a current density of $5.62 \mathrm{~mA} / \mathrm{cm}^{2}$ (Ni'am et al., 2007). Regarding the turbidity in the wastewater removal process, a removal efficiency of $96.74 \%$ was obtained for the indicated current density, thus demonstrating that electrocoagulation technology can improve the quality of wastewater. Rahmani (2008) evaluated parameters such as turbidity, removal time and voltage (5, 10, 20 and 30V); The experimental results confirmed that the removal efficiency depends on the electrolysis time, types of electrodes and the applied current. From the experiment carried out at $10 \mathrm{~V}$ it was found that, for a time of 10 minutes, the removal efficiency of the $\mathrm{Al}$, Fe and Sn electrodes was $93 \%, 91 \%$ and $51 \%$ respectively, confirming that the use of electrodes of Aluminum increased the efficiency of the electrocoagulation process. In another investigation, the voltage $(5,7,9,11$ Volts), current, treatment time (15 minutes), and electrodes were taken into account as steel as cathode and aluminum as anode; Its results showed that in this process it had a significant elimination of the turbidity of the water and a reduction in the Chemical Oxygen Demand (COD) (Gonzalo, 2002; Reyes, 2000) evaluated the treatability of the leachate from the La Esmeralda Landfill (Colombia), by the electrocoagulation method, measuring the decrease in organic load obtained by this process. In this study, the operating conditions were obtained in a batch system (voltage, operating time and type of electrode) for electrocoagulation in the treatment of leachates, considering the best removals of color, turbidity, solids (total, suspended and dissolved) and COD; the maximum removal percentage being $61.70 \%$ of total suspended solids. (Rincón et al., 2009), evaluated the results obtained in the treatment of vinasse from an alcohol distillery through an electrocoagulation - electroflotation process. Different operating variables such as initial $\mathrm{pH}$ of the solution, current density and concentration of $\mathrm{NaCl}$, as electrolyte support, were evaluated in a factorial design, using aluminum electrodes. The results indicate that this technique could be used in the stillage concentration process. Total solids removal of $37 \%$ was obtained without using an electrolytic support. 


\section{SE \\ Engineering}

Vol. 4, $\mathrm{N}^{\circ} 2,2020$
Journal of Sciences and

Copyright @ 2020, CINCADER.

ISSN 2523-9503

DOI: https://doi.org/10.32829/sej.v4i2.192

During electrolysis, a series of physical and chemical processes take place that allow the removal of pollutants. In these processes the metals connected to the anode of the cell are dissolved and a range of coagulant species and hydroxides are formed which destabilize and coagulate the suspended particles, in addition to absorbing dissolved contaminants (Mejía et al., 2012). In the case of using carbon steel plates both in the anode and in the cathode, the possible main reactions that occur could be:

Reactions at the anode:

$\mathrm{Fe}(\mathrm{s}) \longrightarrow \mathrm{Fe}^{(2+)}+2 \mathrm{e}^{-}$

$\mathrm{Fe}(\mathrm{s}) \longrightarrow \mathrm{Fe}^{(3+)}+3 \mathrm{e}^{-}$

$2 \mathrm{H}_{2} \mathrm{O}$

$\longrightarrow 4 \mathrm{H}^{+}+\mathrm{O}_{2(\mathrm{~g})}+4 \mathrm{e}^{-}$

From the equations presented, most of the investigations assume that the main dissolution of iron is that of valence +2. (Barrera-Díaz et al, 2003a); (Pretorius et al, 1991).

Reactions at the cathode:

$2 \mathrm{H}_{2} \mathrm{O}+2 \mathrm{e}^{-} \longrightarrow \mathrm{H}_{2}(\mathrm{~g})+2 \mathrm{OH}^{-}$

There is a theory that direct reduction of cations at the cathode can occur (Pretorius et al., 1991). On the other hand, there are other types of reactions in the areas close to the Fe 2+ ions generated at the anode, such as the reduction of chromium, such a reaction could be written:

$\mathrm{CrO}_{4}^{2-}+3 \mathrm{Fe}^{2+}+4 \mathrm{H}_{2} \mathrm{O} \longrightarrow \mathrm{Cr}^{3+}+3 \mathrm{Fe}^{3+}+8 \mathrm{OH}^{-}$

Once the chromium $3+$ cations have been obtained, and the increase in $\mathrm{pH}$ due to the production of hydroxide ions in the cathode (reaction 4), this induces the precipitation of trivalent chromium to its corresponding hydroxide, such a reaction would be:

$\mathrm{Cr}^{3+}+3 \mathrm{OH}^{-} \longrightarrow \mathrm{Cr}(\mathrm{OH})_{3}$

Many factors are involved in the electrocoagulation process and some of these factors have a greater influence on the process. The $\mathrm{pH}$ influences the efficiency of the process, it has been determined in some cases that the highest efficiency in the removal of a contaminant occurs within a specific $\mathrm{pH}$ range, and even this range can be wide. In general terms, the best removals have been obtained for $\mathrm{pH}$ values close to 7 . Examples of this situation can be seen in the removal of arsenic in drinking water, where the highest percentage of removal of arsenic occurs at $\mathrm{pH}$ between 6 and 8 and the best removals of turbidity and COD in the waters of the textile industry occur at $\mathrm{a} \mathrm{pH}$ of 7 . The reactions that occur during the electrocoagulation process give the aqueous medium whose $\mathrm{pH}$ variations are in the range from 1 to 3 . Especially in alkaline wastewater, this property prevents large changes in $\mathrm{pH}$, with which the dosages of chemical substances to regulate the $\mathrm{pH}$ are lower (Hunsom et al., 2005). As the electrical variables in the electrocoagulation process are the parameters that most influence the removal of the contaminant from a wastewater and are linked to economic factors, greater attention should be paid to their study. Removal efficiency and energy consumption increase with increasing current density. For some conductivities of the aqueous medium, energy consumption increases proportionally with increases in conductivity, which leads to higher energy consumption. For high energy consumptions there are losses due to the transformation of electrical energy into heat, producing an increase in the temperature of the aqueous medium. The current supply to the electrocoagulation system determines the amount of aluminum $\mathrm{Al}^{+3}$ or iron $\mathrm{Fe}^{+2}$ ions, released by the respective electrodes. In general, an increase in current density generates an increase in pollutant removal. Too high a current density would cause a significant decrease in efficiency. The selection of the current density could be made taking into account other operating parameters, such as $\mathrm{pH}$ and temperature (Holt et al., 2004). An increase in electrical conductivity in turn generates an increase in current density. When the voltage supplied to the electrocoagulation cell is kept constant and additionally the conductivity increases, keeping the current density constant, there is a decrease in the applied voltage. The addition of some electrolytes such as $\mathrm{NaCl}$ or $\mathrm{CaCl} 2$ generates an increase in the conductivity of the wastewater. In addition, it has been found that chlorine ions can reduce the adverse effects of ions such as $\mathrm{HCO}^{3-}$ and $\mathrm{SO}^{4=}$ since the presence of carbonate or sulfate ions can lead to the precipitation of $\mathrm{Ca}^{+2}$ and $\mathrm{Mg}^{+2}$, producing an insoluble layer deposited on the electrodes that would increase the potential between them, thus decreasing the efficiency of the current. It is recommended, however, that for a normal electrocoagulation process, amounts of $\mathrm{Cl}^{-}$are kept around $20 \%$. The effects of temperature on electrocoagulation have not been much investigated, but it has been found that the efficiency in the current increases initially until reaching $60{ }^{\circ} \mathrm{C}$, point where it becomes maximum and then decreases. The increase in efficiency with temperature is 


\section{SE \\ Vol. 4, $\mathrm{N}^{\circ} 2,2020$ \\ Journal of Sciences and Engineering}

Copyright (C) 2020, CINCADER.

ISSN 2523-9503

DOI: https://doi.org/10.32829/sej.v4i2.192

attributed to the increase in the destruction activity of the aluminum oxide film on the surface of the electrode (Ruiz, 2005).

\section{Materials and Methods}

The sample consisted of 30 liters of artificial chrome plating effluents. Table 1 offers information on the effluent used. Table 2 indicates the variables and their levels used in the present investigation. Figure 1 shows the experimental sequence developed in the present investigation.

Table 1. Initial characterization of the artificial chrome effluent used in the research

\begin{tabular}{|c|c|}
\hline Property & Initial value \\
\hline Temperature $\left({ }^{\circ} \mathrm{C}\right)$ & 23.5 \\
\hline $\mathrm{pH}$ & 3.8 \\
\hline Hexavalent Chromium $(\mathrm{ppm})$ & 20 \\
\hline
\end{tabular}

Table 2. Levels of the study variables

\begin{tabular}{|l|c|}
\hline Independent variables of study & Study levels \\
\hline Factor $(\mathrm{A}):$ Electrocoagulation time $(\mathrm{min})$ & 20,40 y 60 \\
\hline Factor $(\mathrm{B}):$ Electrode area/effluent volume ratio $\left(\mathrm{m}^{2} / \mathrm{L}\right)$ & $0.0456 ; 0.0684 ; 0.0912$ \\
\hline \multicolumn{2}{|c|}{ Dependent variable of study } \\
\hline \multicolumn{2}{|c|}{ Reduction percentage of hexavalent chromium } \\
\hline
\end{tabular}
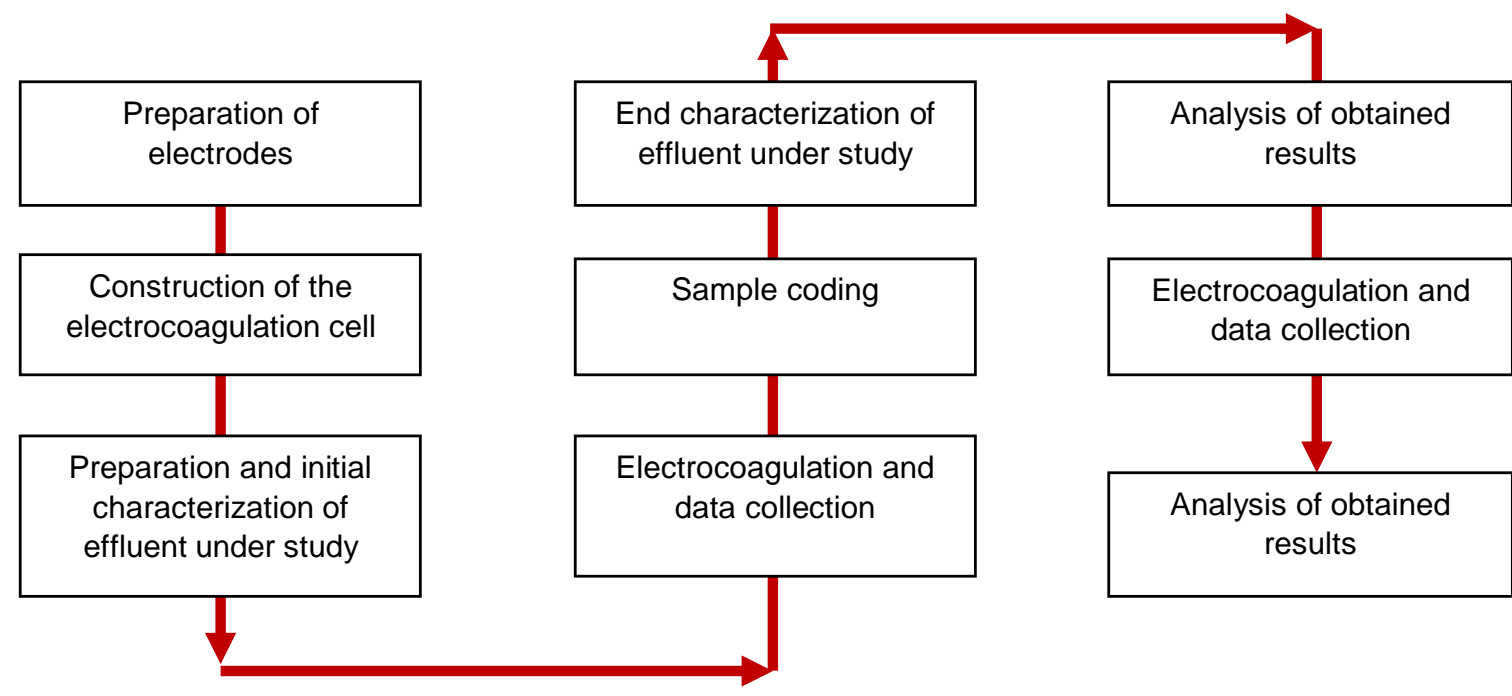

Figure 1. Block diagram of the experimental procedure

\section{1.- Preparation of electrodes:}

The electrodes used were made of A36 structural steel, the same ones that were cut to the following dimensions of $(5 \times 5 \times 0.2) \mathrm{cm}$, taking into account that they should not have any surface contaminants such as oils, grease or dust; They proceeded to be gently sanded and washed with detergent, rinsed with tap water, then degreased with thinner, dried with a cloth; then weigh and encode them.

\section{2.- Construction of the electrocoagulation cell:}

Made of transparent plastic material, it has a capacity of $0.30 \mathrm{~L}$, with a square section of $5 \mathrm{~cm}$ on each side. The scheme of the electrocoagulation system used in this case is shown in figure 2 . The effective area used 


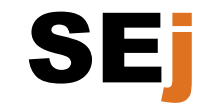

Vol. 4, $\mathrm{N}^{\circ} 2,2020$

\section{Journal of Sciences and \\ Engineering}

Copyright (C) 2020, CINCADER.

ISSN 2523-9503

DOI: https://doi.org/10.32829/sej.v4i2.192

\section{CINCADER}

Centre of Research and Training for

Regional Development

Online at www.journals.cincader.org

was $2.28 \times 10^{-3} \mathrm{~m}^{2}$ per electrode. Table 3 shows in summary form the conditions used for the electrocoagulation process carried out in the present investigation.

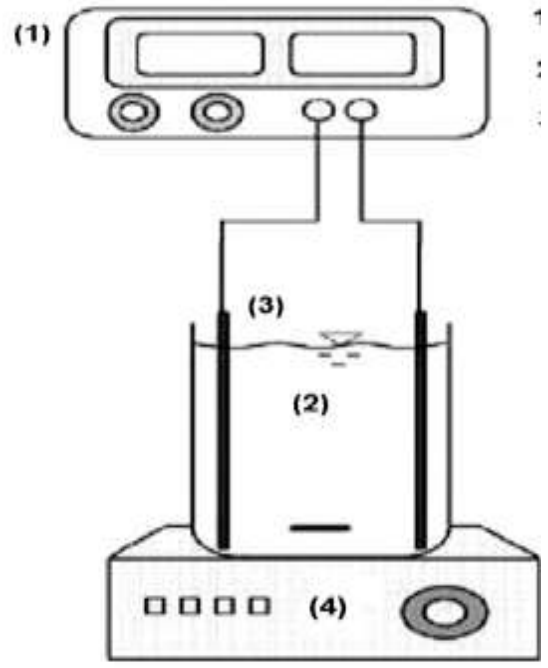

Where:

1.- Current source

2.- Electrocoagulation cell

3.- Steel electrodes

4.- Magnetic stirrer

Figure 2. Diagram of the installation of the electrocoagulation cell used.

Table 3. Operating conditions for electrocoagulation cell

\begin{tabular}{|c|c|}
\hline Sample: Chroem plating artificial effluent & Number of electrodes: variable \\
\hline Treated/Assay Volume: $0.1 \mathrm{~L}$ & Electrodos separation: variable \\
\hline Used voltage: $3.0 \mathrm{~V}$. & Cathode: minimum 01 / steel \\
\hline Treatment time: variable & Anode: minimum 01 / steel \\
\hline Operation type: batch & $\begin{array}{l}\text { Electrode size: } \\
\left(5^{*} 5^{*} 0.2\right) \mathrm{cm}\end{array}$ \\
\hline \multicolumn{2}{|c|}{ Electrode area/effluent volumen ratio = variable } \\
\hline \multicolumn{2}{|c|}{ Test time $=$ variable } \\
\hline \multicolumn{2}{|c|}{ Initial concentration of hexavalent chromium: 20 ppm } \\
\hline
\end{tabular}

\section{3.- Electrocoagulation:}

The electrocoagulation process was carried out in the cell shown in figure 2, using steel electrodes; data such as $\mathrm{pH}$, conductivity and electrical variables were taken three times in each test at equal intervals; the mass variations of the electrodes were made at the beginning and end of each electrocoagulation test. The samples tested were subjected to a chemical analysis, in order to evaluate the quantitative variation of the concentration of hexavalent chromium in the effluent under study, in such a way that it was possible to verify the reduced ppms of chromium, by using the electrocoagulation method, according to the conditions already mentioned.

\section{Results}

3.1. Reduction percentage of hexavalent chromium:

Table 4 shows the average data corresponding to the amount of hexavalent chromium present after each electrocoagulation test; While in table 5 , the average data corresponding to the percentage of reduction of hexavalent chromium of artificial chrome plating effluents are presented; after the application of the study variables, in the electrocoagulation process. 


\section{SE \\ Journal of Sciences and Engineering}

Vol. 4, $\mathbf{N}^{\circ} 2,2020$

Copyright @ 2020, CINCADER.

ISSN 2523-9503

DOI: https://doi.org/10.32829/sej.v4i2.192

Table 4. Average values of hexavalent chromium at the end of the electrocoagulation tests

\begin{tabular}{|c|c|c|c|c|}
\hline & & Electr & ffluent $\mathrm{v}$ & $\left(\mathrm{m}^{2} / \mathrm{L}\right)$ \\
\hline & & Percentac & ual hexa & nium (ppm) \\
\hline \multirow{4}{*}{$\begin{array}{l}\text { Treatment time } \\
\text { (minutes) }\end{array}$} & & 0.0456 & 0.0684 & 0.0912 \\
\hline & 20 & 13.33 & 12.45 & 11.51 \\
\hline & 40 & 7.31 & 6.46 & 5.71 \\
\hline & 60 & 2.86 & 2.28 & 1.67 \\
\hline
\end{tabular}

Table 5. Reduction percentage values of average hexavalent chromium

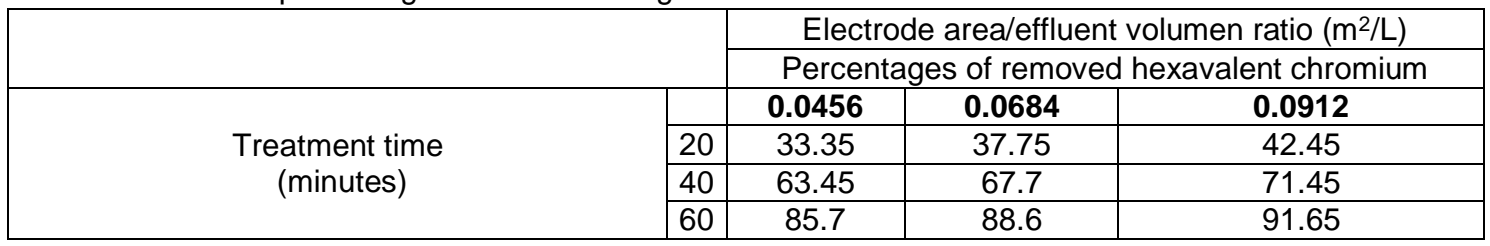

Figure 3 shows how the treatment time decreases the hexavalent chromium concentration from $20 \mathrm{mg} / \mathrm{L}$ to $1.67 \mathrm{mg} / \mathrm{L}$ in the best of cases, which is a value corresponding to the $91.65 \%$ reduction in hexavalent chromium; the same trend of reduction of hexavalent chromium is also appreciated with the variation of the ratio of electrode area / volume of effluent, although the effect of treatment time is much more pronounced than the effect of the ratio of area / volume, since in table 5 it can be seen in each column that corresponds to a certain area / volume ratio, the increase in the percentage of reduction of hexavalent chromium is approximately $30 \%$; while the increase in the reduction percentage in the case of the rows of the same table does not exceed $5 \%$ at most. In the case of the increase in the area / volume ratio, we could say that the improvement in the percentage of reduction of hexavalent chromium is probably due to the reduction in resistivity between iron electrodes, this means less ion travel, greater movement capacity of these; it is appropriate to note that the electrical voltage variable was not altered. Therefore, the quantity of electrons supplied is the same, having a higher transfer capacity, slightly improving the cell current; Therefore, the improvement in the reduction percentage is small, this could lead us to say as mentioned in Rodie and Hardenberg (1987); that electrical variables are the motor of electrocoagulation and in this case an improvement could occur with respect to the area / volume variable if and only if the voltage applied to the cell is increased.

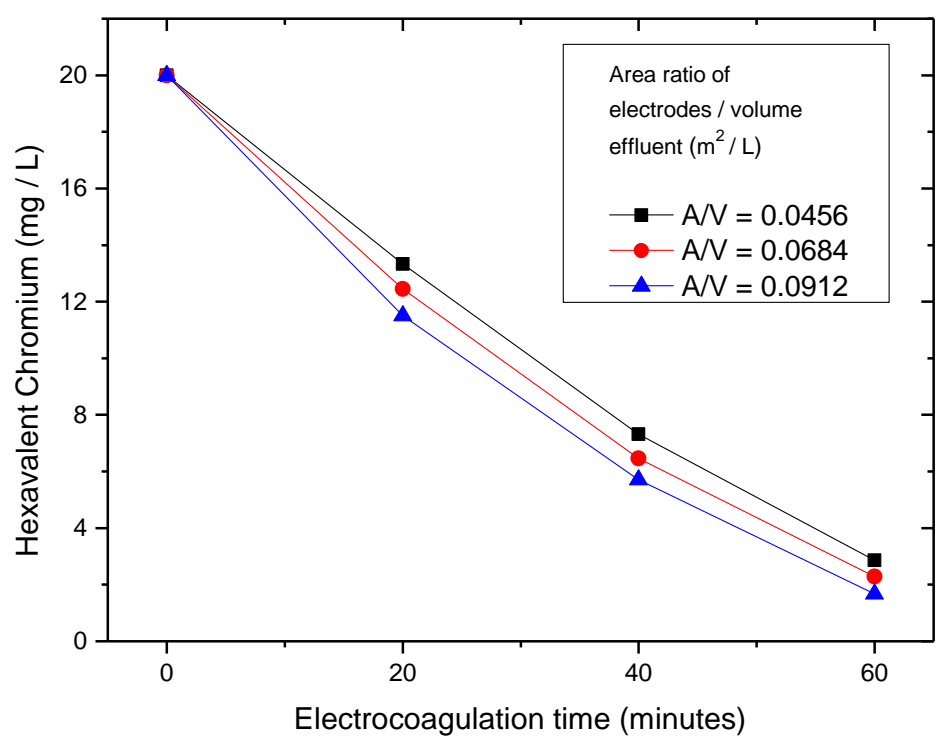

Figure 3. Effect of electrocoagulation time at different $\mathrm{A} / \mathrm{V}$ values on hexavalent chromium concentration. 


\section{Journal of Sciences and Engineering}

Vol. 4, $\mathrm{N}^{\circ} 2,2020$

Centre of Research and Training for

Regional Development Online at www.journals.cincader.org

Copyright @ 2020, CINCADER.

ISSN 2523-9503

DOI: https://doi.org/10.32829/sej.v4i2.192

Figure 4 shows the effect of the mentioned variables on the percentage of reduction of hexavalent chromium in the chrome plating effluents.

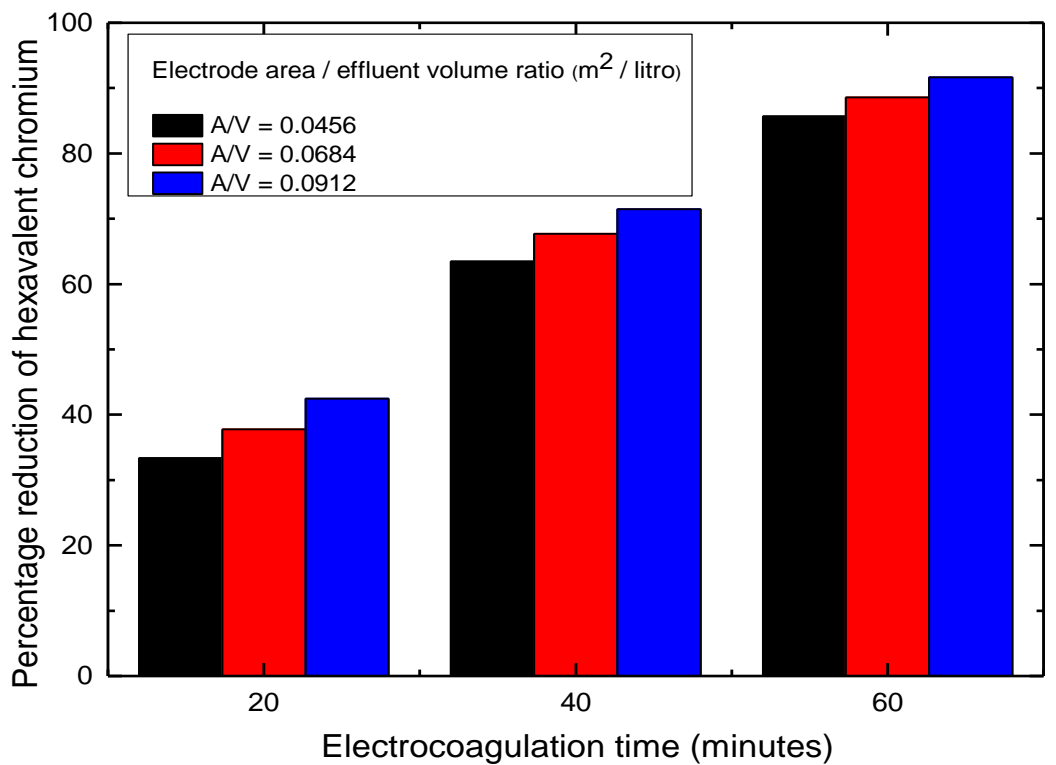

Figure 4. Percentage reduction of hexavalent chromium

In order to give a better explanation to the results obtained on the percentage of reduction of hexavalent chromium, of the artificial chromium plating effluents, additional data was taken such as the variation of $\mathrm{pH}$ of the effluent during the electrocoagulation process, the data was shown in table 6 , as well as in figure 5 , in addition the variation of iron concentration in the effluent was evaluated, theoretically and experimentally, in order to help us in explaining what happened and give us an idea of the efficiency in the anode, said results are shown in table 7 and in figure 6 . Theoretical calculations of iron dissolution $(\mathrm{Fe} 2+$ and $\mathrm{Fe} 3+)$, were carried out by applying the Faraday equation (A detailed example of this type of calculation is presented in the annexes); the experimental dissolution calculations were obtained by the weight variation of the anodes of the cell; in their respective electrocoagulation times; From these, the experimental anodic dissolution rate of iron in the electrocoagulation cell was obtained; all these data are shown and compared in figure 6.

Table 6. $\mathrm{pH}$ variations in the electrocoagulation cell

\begin{tabular}{|c|c|c|c|c|}
\hline & \multirow{2}{*}{\multicolumn{3}{|c|}{ Electrode area/effluent volumen ratio $\left(\mathrm{m}^{2} / \mathrm{L}\right)$}} \\
\hline & & \multicolumn{2}{|c|}{$\mathrm{pH}$ of effluent } & \\
\hline & & 0.0456 & 0.0684 & 0.0912 \\
\hline \multirow{6}{*}{ Electrocoagulation time } & 0 & 3.8 & 3.8 & 3.8 \\
\hline & 10 & 4.2 & 4.78 & 5.01 \\
\hline & 20 & 6.45 & 6.72 & 7.02 \\
\hline & 30 & 7.95 & 8.25 & 8.34 \\
\hline & 40 & 8.2 & 8.7 & 8.8 \\
\hline & 60 & 8.6 & 8.9 & 9 \\
\hline
\end{tabular}




\section{SE \\ Journal of Sciences and Engineering}

Vol. 4, $\mathbf{N}^{\circ} 2,2020$

Copyright (c) 2020, CINCADER.

ISSN 2523-9503

DOI: https://doi.org/10.32829/sej.v4i2.192
Centre of Research and Training for

Regional Development Online at www.journals.cincader.org

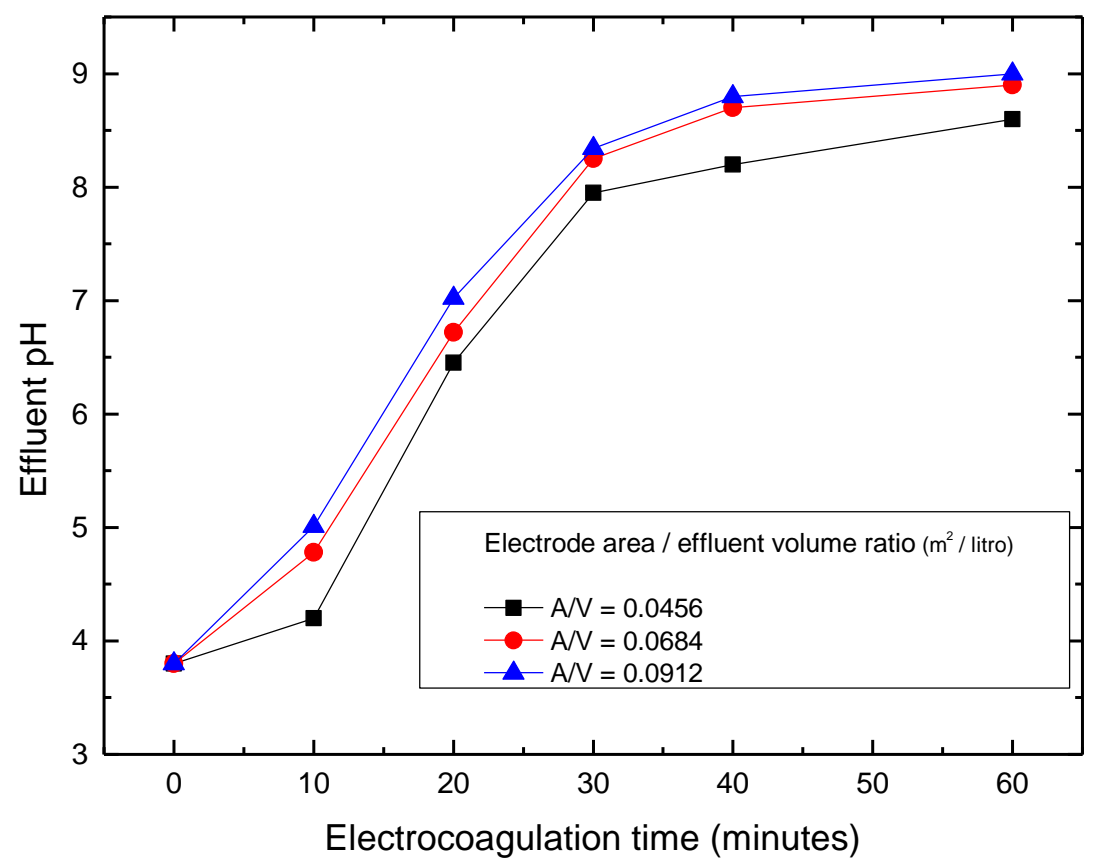

Figure 5. Effluent $\mathrm{pH}$ variation during electrocoagulation process

The electrocoagulation process is used in the treatment of wastewater in a wide spectrum of industries, this process focuses on the application of direct current in an electrolytic cell, in which chemical reactions take place both in the anodes and in the cathodes Thus, in the present research work, steel anodes and cathodes were used (since these are inexpensive and any coating plant has them); achieving a maximum reduction percentage of hexavalent chromium from artificial chrome effluents, of $91.65 \%$, with respect to the initial concentration $(20 \mathrm{mg} / \mathrm{L})$, for a test time of 60 minutes and a ratio of electrode area / effluent volume 0.0912 $\mathrm{m}^{2} / \mathrm{L}$, showing the high efficiency of this effluent treatment method; this can be seen in table 7 of the results presentation section.

Table 7. Theoretical and experimental data on the rate of dissolution of iron in the electrocoagulation process

\begin{tabular}{|c|c|c|c|c|c|c|c|}
\hline \multicolumn{2}{|c|}{$\begin{array}{c}\text { Theoretical dissolutio } \\
\text { rate } \mathrm{Fe}^{2+}\end{array}$} & \multicolumn{2}{|c|}{$\begin{array}{c}\text { Theoretical dissolutio } \\
\text { rate } \mathrm{Fe}^{3+}\end{array}$} & \multicolumn{2}{|c|}{$\begin{array}{c}\text { Experimental } \\
\text { dissolution rate } \mathrm{Fe}\end{array}$} & \multicolumn{2}{|c|}{$\begin{array}{l}\text { Experimental formation } \\
\text { rate } \mathrm{Fe}^{3+}\end{array}$} \\
\hline \multicolumn{2}{|c|}{$\begin{array}{l}\mathbf{0 . 8 6} \mathbf{~ m g} / \mathbf{m i n u t e} \\
\text { (Faraday's Law) }\end{array}$} & \multicolumn{2}{|c|}{$\begin{array}{l}0.57 \mathbf{~ m g} / \text { minute } \\
\text { (Faraday's Law) }\end{array}$} & \multicolumn{2}{|c|}{$\begin{array}{c}\mathbf{0 . 8 7 4} \mathbf{~ m g / m i n u t e} \\
\text { (average value) }\end{array}$} & \multicolumn{2}{|c|}{ ND } \\
\hline Time & $\begin{array}{c}\mathrm{mg} \\
\text { dissolved }\end{array}$ & Time & $\begin{array}{c}\mathrm{mg} \\
\text { dissolved }\end{array}$ & Time & $\begin{array}{c}\mathrm{mg} \\
\text { dissolved }\end{array}$ & Time & $\mathrm{mg}$ \\
\hline 20 & 17.2 & 20 & 11.4 & 20 & 18.1 & 20 & ND \\
\hline 40 & 34.4 & 40 & 22.8 & 40 & 33.5 & 40 & 8.4 \\
\hline 60 & 51.6 & 60 & 34.2 & 60 & 52.7 & 60 & 14.6 \\
\hline
\end{tabular}

ND $=$ No determined $/$ No calculated 


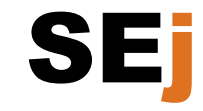

Vol. 4, $\mathrm{N}^{\circ} 2,2020$

\section{Journal of Sciences and Engineering}

Copyright @ 2020, CINCADER.

ISSN 2523-9503

DOI: https://doi.org/10.32829/sej.v4i2.192

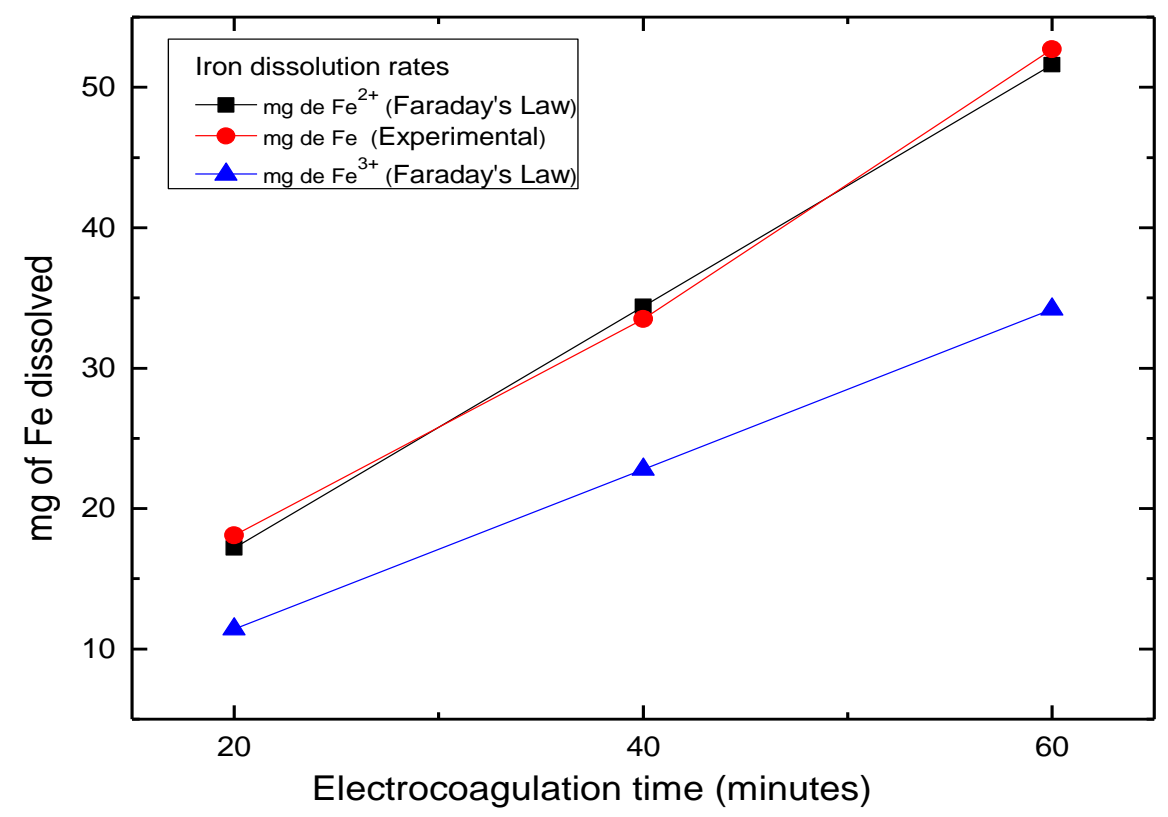

Figure 6. Theoretical and experimental dissolution rates of iron

The reduction of pollutants by means of this method is based on the reactions, ions or molecules, which are generated both in the anode and in the cathode of the electrocoagulation cell, being the one that possibly predominates in the anode. For this case, with equation (1), the dissolution of iron as a divalent cation is favored before the trivalent cation (equation 2) or before the reaction in which the water decomposes releasing oxygen (equation 3), since such As shown in Table 7, the experimental dissolution rate of iron is $0.874 \mathrm{mg} /$ minute; comparing this data with the corresponding divalent and trivalent iron dissolution rates obtained by Faraday's equation and as shown in figure 6, the dissolution rate is better adjusted to that indicated by Faraday to the dissolution of divalent iron; Furthermore, no bubbling was observed at the anode of the cell during the tests, this would mean that the current supplied by the external equipment would be used in the formation of divalent iron cations, having an efficiency of almost $100 \%$ at the anode, (BarreraDiaz et al., 2003b; Pretorius et al., 2001; Hunsom et al., 2004; Holt et al., 2005).

In the case of the cathode, although equation (4) is probable, we must not forget that the reference indicates that there is the possibility of a direct reduction on the cathode of the electrocoagulation cell; in this case the equation that would represent this statement could be:

$$
\mathrm{CrO} 4{ }^{(-2)}+3 \mathrm{e}^{-}+4 \mathrm{H}_{2} \mathrm{O}=\mathrm{Cr}{ }^{(+3)}+8 \mathrm{OH}^{(-)}
$$

Despite this, equation (5) would be a preferential reaction in the reduction of hexavalent to trivalent chromium, since if equation (7) were to be preferred, it would have to compete with equation (4), which would indicate a low or no formation of hydrogen bubbles in the cathode, which was not the case, on the contrary the bubbling in the cathode is vigorous during the tests, another detail that reaffirms this statement is the fact that it has already been mentioned that the production of divalent iron in the anode is most likely, so it would be used as an agent for the reduction of hexavalent chromium preferably, rather than a direct reduction in the cathode, in addition to that in table 7 it can be seen that although the experimental dissolution rate of the Iron is better suited to the formation of divalent cations (Faraday), trivalent cations, although in much smaller amounts than theoretically expected, are present, which are probably formed from part go from equation (5).

Therefore, the preferential reaction for the reduction of hexavalent to trivalent chromium probably, for the test conditions carried out, would be:

$$
\mathrm{CrO}_{4}^{2-}+3 \mathrm{Fe}^{2+}+4 \mathrm{H}_{2} \mathrm{O} \longrightarrow \mathrm{Cr}^{3+}+3 \mathrm{Fe}^{3+}+8 \mathrm{OH}^{-} \ldots . .(5)
$$


But the electrocoagulation process still allows the reduction to continue (since equation 5 allows the reduction from +6 to +3 ): Remember that equations ( 4 and 5) indicate an increase in the concentration of $\mathrm{OH}$ - ions, an increase in the $\mathrm{pH}$ of the effluent, this statement is supported by figure 5 . Around the first 10 15 minutes the $\mathrm{pH}$ of the solution increases significantly to almost 9 at $40-45$ minutes; The increase in $\mathrm{pH}$ results in the formation and stability of chromium hydroxide, which is formed by equation (6), which is appreciable in a species stability diagram (Pourbaix Diagram), they also reached such a conclusion the research works of the references (Celenza, 2000; Ramallo, 1993).

Rigola (1989) states that the reaction that occurs at the anode and cathode of an electrocoagulation cell, allows the formation of species that react, destabilize or drag the contaminants present, in this case the divalent iron cations formed in the anode and $\mathrm{OH}$ - radicals are the tools for the reduction and precipitation of the hexavalent chromium present.

\section{Conclusions}

The maximum reduction percentage achieved was $91.65 \%$, with respect to the initial concentration (20 $\mathrm{mg} / \mathrm{L})$, for a test time of 60 minutes and a ratio of electrode area / effluent volume of $0.912 \mathrm{~m} 2 / \mathrm{L}$.

The electrocoagulation time and the electrode area/effluent volume ratio influence the percentage of hexavalent chromium reduction of the chrome plating artificial, as supported by the ANOVA and $F$ test.

\section{Acknowledgments}

Special thanks to the Composite Materials Laboratory of the School of Materials Engineering of the Universidad Nacional de Trujillo for their support in the development of this research.

\section{References}

Barrera-Díaz, Carlos \& Palomar, Manuel \& Romero-Romo, Mario \& Delgadillo, Sergio. 2003a. Chemical and electrochemical considerations on the removal process of hexavalent chromium from aqueous media. Journal of Applied Electrochemistry. 33. 61-71. 10.1023/A:1022983919644.

Barrera-Diaz, M. Palomar-Pardave, M. Romero-Romo, S. Martinez. 2003b. Chemical and electrochemical considerations on the removal process of chromium from aqueous, Journal. Appl. Electrochem.

Bazrafshan, Edris \& Mahvi, Amir \& Naseri, S. \& Mesdaghinia, AR. . 2008. Performance evaluation of electrocoagulation process for removal of chromium (VI) from synthetic chromium solutions using iron and aluminum electrodes. Turkish Journal of Engineering and Environmental Sciences32. 5966.

Celenza, G.J. 2000. Industrial Waste Treatment Process Engineering guide: Biological Processes, Vol II, Technomic Publishing. 207.

Diario el Peruano. Decreto Supremo № 037-2008- PCM - PRODUCE. Límites máximos permisibles para actividades industriales. Lima, miércoles 14 de mayo 2008. Lima-Perú.

Gonzalo, M. 2002. Electrocoagulación de aguas residuales. 34.

Holt, G.W. Barton, C.A. Mitchell, 2005. Deciphering the science behind electrocoagulation to remove suspended clay particles from water. Water Sci. Technol. [paper].

Holt, P., Barton, G., Mitchell, C. 2004. Deciphering the science behind electrocoagulation to remove suspended clay particles from water. Water science and technology: a journal of the International Association on Water Pollution Research. 50. 177-84. 10.2166/wst.2004.0711.

Hunsom, K. Pruksathorn, S. Damronglerd, H. Vergnes. 2005. Electrochemical treatment of heavy metals (Cu2+, $\mathrm{Cr} 6+, \mathrm{Ni2}+)$ from industrial effluent and modeling of copper reduction, Water S.A. [paper].

Hunsom, M., Pruksathorn, K., Damronglerd, S., Vergnes, H., Duverneuil, P. 2004. Electrochemical treatment of heavy metals (Cu2+, $\mathrm{Cr} 6+\mathrm{Ni2}+$ ) from industrial effluent and modeling of copper reduction. Water research. 2004. 39. 610-6. 10.1016/j.watres. 10.011.

Mejía, A., Ruíz, Á., Garces Giraldo, L. 2012. La Electrocoagulación: retos y oportunidades en el tratamiento de aguas.

Metcalf \& Eddy. 1995. Ingeniería de Aguas Residuales: Tratamiento, Vertido y Reutilización, McGraw-Hill. 


\section{Journal of Sciences and Engineering}

Vol. 4, $\mathrm{N}^{\circ} 2,2020$

Copyright (c) 2020, CINCADER.

ISSN 2523-9503

DOI: https://doi.org/10.32829/sej.v4i2.192

\section{A publication of}

\section{CINCADER}

Centre of Research and Training for

Regional Development Online at www.journals.cincader.org

Morello, Carmela. 2020. Programa de minimización de residuos industriales. Estudio en la industria de galvanoplastia. Estudio de caso de una empresa de galvanoplastia en Lima - Perú. Solicitud de investigación.

Ni'am, M., Othman, F., Sohaili, J., Fauzia, Z. 2007. Removal of COD and turbidity to improve wastewater quality using electrocoagulation technique. The Malaysian Journal of Analytical Sciences. 11. 198205.

Pretorius, W.A., Johannes, W.G., Lempert, G. 1991. Electrolytic iron flocculant production with a bipolar electrode in series arrangement. 17. 133-138.

Pretorius, W.G. Johannes, G.G. Lempert, 2001. Electrolytic iron flocculant production with a bipolar electrode in series arrangement, Water S.A.

Rahmani, Ar. 2008. Removal of water turbidity by the electrocoagulation method. Journal of research in health sciences. 8. 18-24.

Ramallo, R.S. 1993. Tratamiento de Aguas Residuales, Reverté.

Reyes D., Mercado "Tratabilidad por electrocoagulación de los lixiviados de Relleno Sanitario la Esmeralda" Trabajo de Grado. Universidad Nacional de Colombia. December 2000.

Rigola, M. 1989. Tratamiento de aguas industriales, Marcombo.

Rincón, J., Marriaga-Cabrales, N., Machuca-Martínez, F. 2009. Remoción de sólidos totales de vinazas por electrocoagulación - electroflotación. Dyna. 76.

Rodie B. y Hardenberg. 1987. Ingeniería Sanitaria. Ed. Continental S.A. de C.V. México D.F.

Ruiz, Álvaro. 2005. La electrocoagulación: una alternativa para el tratamiento de aguas residuales. Revista Lasallista de Investigación.

Salvadó, Enrique. 2001, Perspectiva general del cromado industrial: características físicas del recubrimiento y tipos de cromado. Anales de la Real Sociedad Española de Química, ISSN 1575-3417, №. 3, pags. 19-27. 